\title{
20
}

\section{Historical significance of the Southwest Islands of Palau}

\author{
Michiko Intoh \\ National Museum of Ethnology, Osaka, Japan \\ intoh@idc.minpaku.ac.jp
}

\section{Introduction}

Micronesia occupies the northwestern corner of Oceania. Most of the islands are scattered in the northern hemisphere, except for Kiribati. The Southwest Islands of Palau are located at the southwestern corner of Micronesia. The area is adjacent to the islands in Melanesia, Indonesia and the Philippines and forms a significant locale to identify human movements around, and particularly into, Micronesia.

While the Southwest Islands of Palau are relatively isolated compared with other island groups in Micronesia, there are a number of coral islands scattered throughout Micronesia whose inhabitants developed various living strategies to enable them to survive in a resourcelimited environment. The most recognised strategy was continuing cultural contacts with other islands to acquire goods and human resources (Intoh 2008). One such example in Micronesia is the sawei exchange system that was developed between Yap and the coral islands in the Central Caroline Islands. Another example is the two large trading networks developed within the archipelago of the Marshall Islands (Alkire 1978).

Reconstructing the way of life of these island groups, particularly the external relations built between coral islands and other islands, should provide new insights to enable us to better understand the adaptation strategies required to survive in a resource-limited environment.

\section{Geography: Linking Micronesia and Island Southeast Asia}

The Palau archipelago consists of four island groups, Kayangel Atoll, Babeldaob, Peleliu and Angaur, and the Southwest Islands (Figure 1). The cluster of Babeldaob, Peleliu and Angaur forms the main island group. Sonsorol, the northernmost island of the Southwest Islands, lies about $300 \mathrm{~km}$ southwest from Babeldaob.

The Southwest Islands consist of five coral islands and one small islet: Sonsorol and an associated small islet Fana, Pulo Anna, Merir, Tobi and Helen Reef. The southernmost island, Tobi, and Helen Reef are about $550 \mathrm{~km}$ away from Babeldaob. The distance from Tobi to 


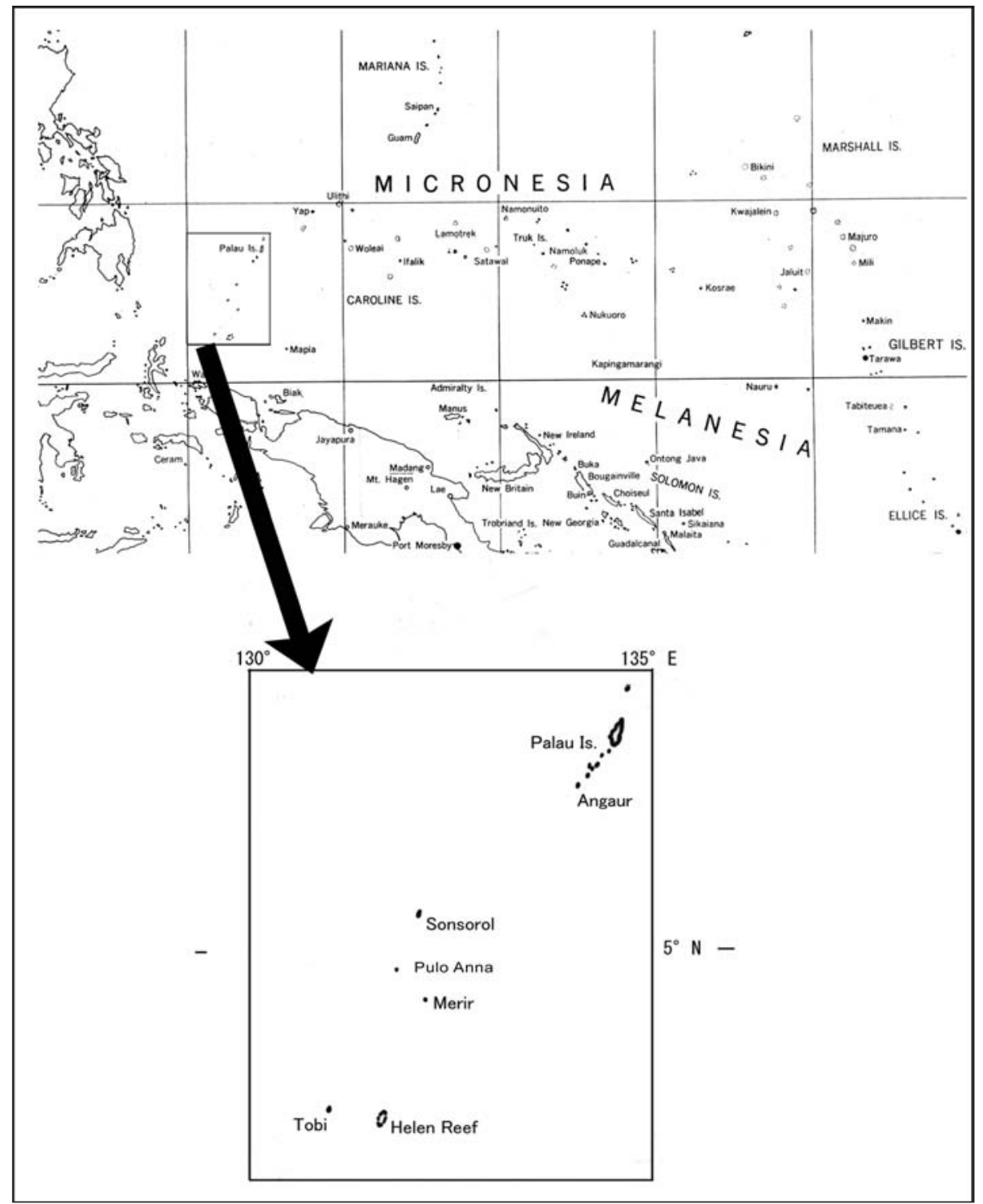

Figure 1. Map of the Southwest Islands of Palau.

Island Southeast Asia or to New Guinea is considerably less. Tobi is only about $280 \mathrm{~km}$ away from Morotai or Halmahera in Indonesia and about $370 \mathrm{~km}$ from the western coast of New Guinea.

Except for Helen Reef, all the Southwest Islands are raised coral islands and the land height varies from $3 \mathrm{~m}$ to $6 \mathrm{~m}$ above sea level. The islands are surrounded by narrow reefs and deep ocean. It is not easy to bring a large boat alongside the islands because of the strong currents outside the reef.

Helen Reef is a large atoll, about $25 \mathrm{~km}$ long and $10 \mathrm{~km}$ wide. Most of the low islets of the atoll are washed by waves at high tide. The total permanent land area is very small, only about $0.03 \mathrm{~km}^{2}$. At European contact in the 18 th century, this atoll was uninhabited. Three government guards, however, are now sent regularly to the atoll in order to watch out for illegal fishing activities.

The land areas of the inhabited Southwest Islands are small - the largest, Sonsorol, is only $1.36 \mathrm{~km}^{2}$, while the smallest, Pulo Anna, is about $0.5 \mathrm{~km}^{2}$ (Table 1). Raised coral islands lack mineral resources. The soil is not rich and plants do not grow well. The animal population is generally low and no mammals were present before contact. Such a limited-resource environment 
Table 1. Location and land area of Southwestern Islands of Palau (after Engbring 1983).

\begin{tabular}{llll}
\hline Islands & Latitude $(\mathrm{N})$ & Longitude $(\mathrm{E})$ & Area $\left(\mathbf{k m}^{2}\right)$ \\
\hline Sonsoror & $5^{\circ} 20^{\prime}$ & $132^{\circ} 13^{\prime}$ & 1.36 \\
Pulo Anna & $4^{\circ} 40^{\prime}$ & $131^{\circ} 58^{\prime}$ & 0.5 \\
Merir & $4^{\circ} 19^{\prime}$ & $132^{\circ} 19^{\prime}$ & 0.9 \\
Tobi & $3^{\circ} 01^{\prime}$ & $131^{\circ} 11^{\prime}$ & 0.6 \\
Helen Reef & $2^{\circ} 59^{\prime}$ & $131^{\circ} 49^{\prime}$ & 0.25 \\
\hline
\end{tabular}

is unlikely to have supported a large population (see Petersen 1999:398-399).

The ocean current around the Southwest Islands is called the Equatorial Countercurrent and flows from the west (near the southern Philippines and Halmahera) throughout the year. This current has to be crossed to navigate to Babeldaob, and it is necessary to navigate against this current when going to Southeast Asia. The navigational environment around the Southwest Islands does not favour navigation to any of the nearby resource-rich islands.

In contrast, it is easy to navigate from the Central Caroline Islands to Yap with the North Equatorial Current that flows from east to west. When a canoe gets lost, it is likely to end up in the Philippines. ${ }^{1}$ It is very likely that one such drifted canoe ended up in the Southwest Islands, as described below.

The current delivers various kinds of flotsam to the Southwest Islands from Island Southeast Asia. During a visit to the Southwest Islands in 2002, a number of large bamboo poles were observed adrift on the beaches of some of the islands. There was even a bamboo raft adrift on the coast of Sonsorol, possibly from one of the Indonesian islands. This may indicate the possibility that humans could also have drifted from some of the islands of Southeast Asia to the Southwest Islands of Palau.

In the early 1900s, Kotondo Hasebe made body measurements of six males and two females from Tobi staying on Babeldaob. He pointed out that their physical characteristics, such as short height, long head and wide nose, were more similar to Malays than to other Southwest Islanders or Caroline Islanders (Hasebe 1928) (Figure 2).

Taro (Cyrtosperma) was planted in large cultivation pits that were dug down to the freshwater level in the central part of the islands. Banana and breadfruit trees were also cultivated. It is not clear whether any domesticated animals were kept on the islands. ${ }^{2}$ As the islands are surrounded by the deep ocean, rich marine resources including migratory fishes are accessible.

\section{History: Isolation and resource management}

The Southwest Islands of Palau were recorded relatively early by the Europeans. After Magellan died in the Philippines, Espinosa directed the vessel Trinidad from Halmahera towards the Mariana Islands in 1522. Sonsorol was sighted and recorded for the first time on this voyage (Hezel and Valle 1972:26). However, the Palau mainland was not well known until 1710. Missionaries staying in the Philippines around the 17th and 18th centuries had heard about a number of small islands scattered east of the Philippines from Carolinians who had drifted ashore in the Philippines, and so desiring to evangelize them, they collected contributions and made requests to the Pope. Expedition ships were obtained from the Spanish king and were sent out several times to look for the Palau islands, but most of the expeditions failed.

In 1710, one of the three ships, the vessel Santissima Trinidad commanded by Francisco Padilla, finally found Sonsorol. Due to the fast current around the island, it took four days 

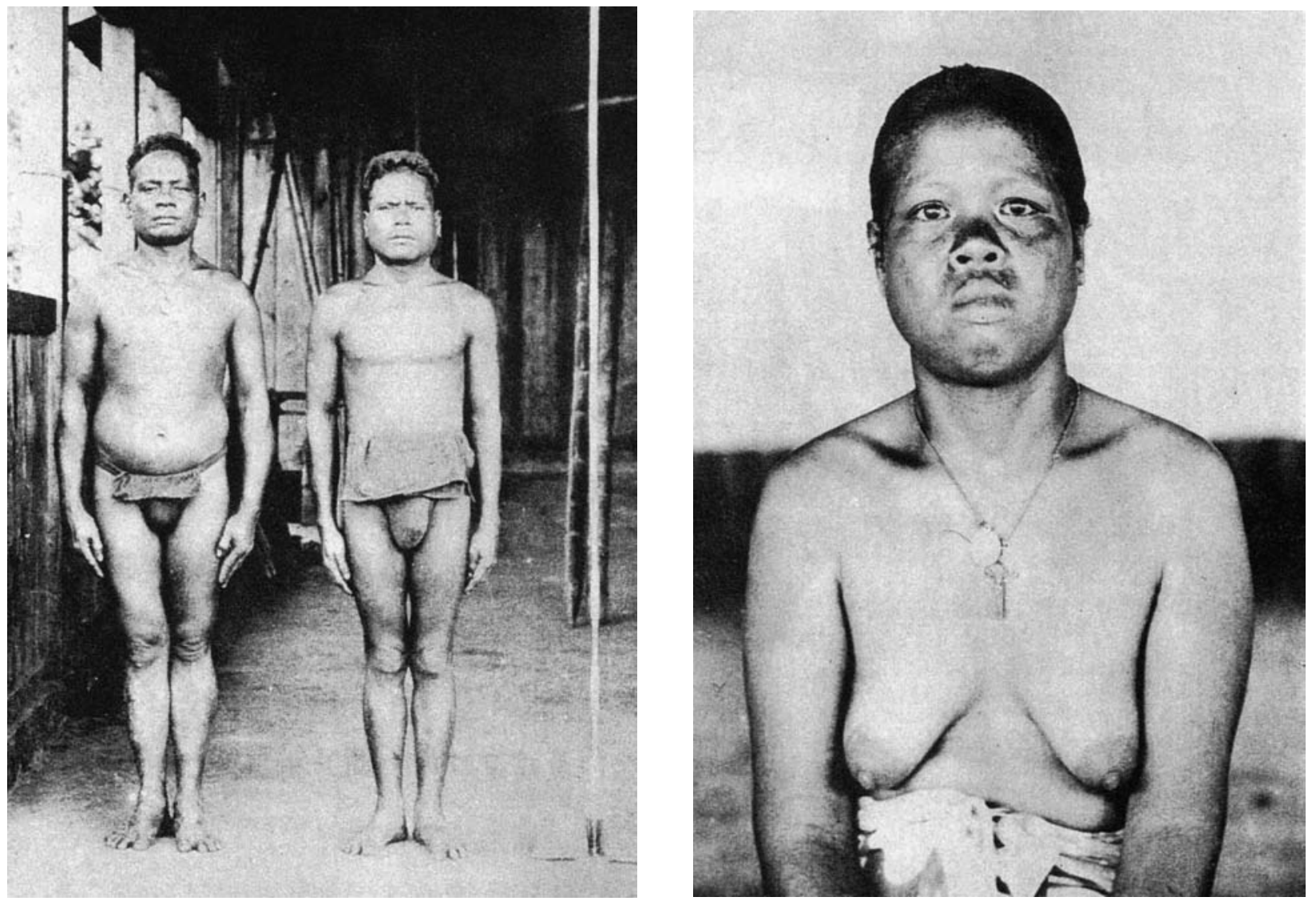

Figure 2. People of the Southwest Islands. Left to right: 2a and 2b, Tobi (after Hasebe 1928); Facing page, left to right: 2c, Merir (after Someki 1945); 2d, Pulo Anna (after Someki 1945).

to approach the reef before two missionaries were able to land. Before the two missionaries returned, the Trinidad had drifted away. While trying to go back to Sonsorol, Trinidad came upon Babeldaob and made a landing there. This visit demonstrates the speed of the ocean current around Sonsorol. The same difficulty was documented in the Japanese historical records (Hasebe 1928).

There were more records of sighting the other Southwest Islands in the late 18th and early 19th centuries. However, few records were made of daily life on the islands. By the early 19th century, Babeldaob had frequent contacts with European ships and obtained iron and guns which were used for internal warfare.

Palau became well known from the published record of the British ship Antelope that ran aground near Koror in 1783. The first direct record of the Southwest Islands was not, however, made until 1836, when Holden published a record of his experiences in Babeldaob and Tobi.

Holden was a seaman of the American whaling ship Mentor that ran aground at the western end of the reef surrounding Palau in 1832. Holden and other seamen landed on Babeldaob and built a large boat. They subsequently left for Canton with three Palauans, leaving three seamen behind as hostages. After several days, they were hit by a storm and started drifting. After nine days, they came close to Tobi and were attacked and captured by Tobians. In November 1834, the sole survivors, two Americans, were rescued by an English ship, Britannia. One of these two was Holden, who subsequently published an account of his experiences (Holden 1836).

According to Holden's description, the lives of hostages on Tobi were very harsh. All of their clothes and belongings were taken away and they were forced to work for the islanders. They had to dig the ground for taro planting with bare hands without tools. On top of this 

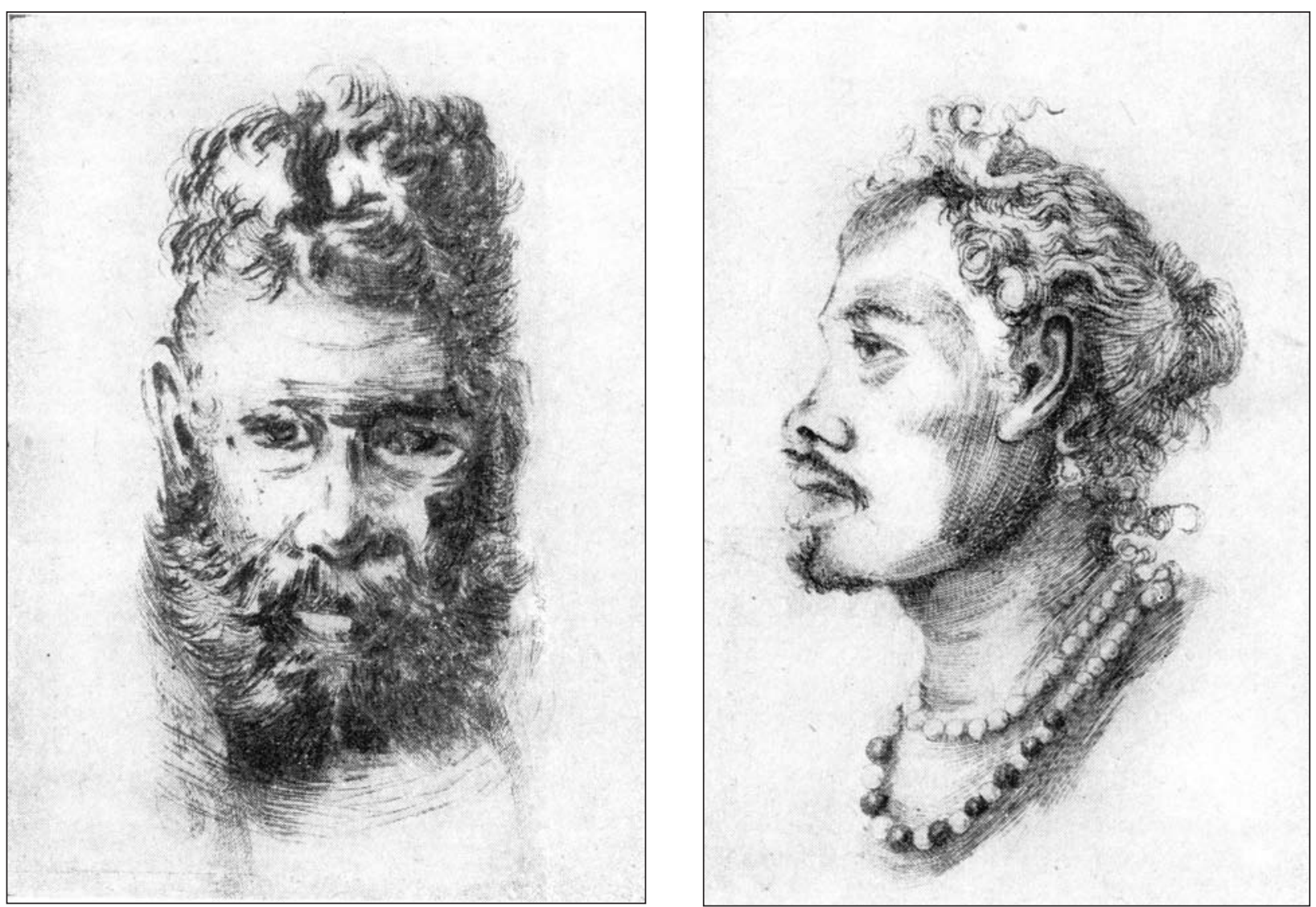

harsh work and the violent treatment by the islanders, starvation from not eating proper food resulted in the deaths of most of the hostages. Food was extremely scarce on the island and the islanders, too, were described as starving. There were frequent fights over the insufficient coconuts and fish. Only five sea turtles were caught during the two years of Holden's stay. It is not clear whether these were normal living conditions on Tobi or whether that year was very unusual. Judging from the reasonably rich living conditions today, with plentiful coconuts and fish, ${ }^{3}$ the severe situation of Holden's time could have been the result of either unusual climatic conditions or over population.

Conditions deteriorated during the two years of Holden's stay. The captured Americans were made to plant taro every day, but did not seem to be engaged for harvesting. It was repeatedly mentioned that food was extremely scarce. It is possible the taro cultivation pit was destroyed by natural hazards, such as typhoon or tidal wave. In fact, a large storm had stranded the Mentor on the reef the previous year, and several big storms hit the island while Holden was there. A number of coconut trees fell down and many coconuts were damaged. Holden also recorded that the taro cultivation pit was filled with sand. Taro does not tolerate saltwater. Once an island is devastated in this way, it takes considerable time for it to recover.

The hostages were made to dig the ground and mix humus with sandy soil by hand for planting taro. When a large storm hit the island, they were made to build a stone wall with large coral boulders to prevent trees from being washed out. It seems that land modification as a scheme for resource management was very active on the island (Figure 3). Visiting other islands for help was not mentioned in the record.

It is also unusual that fish were described as being scarce. This contradicts evidence provided by ethnographic and archaeological data. A number of fishing methods were described in the 


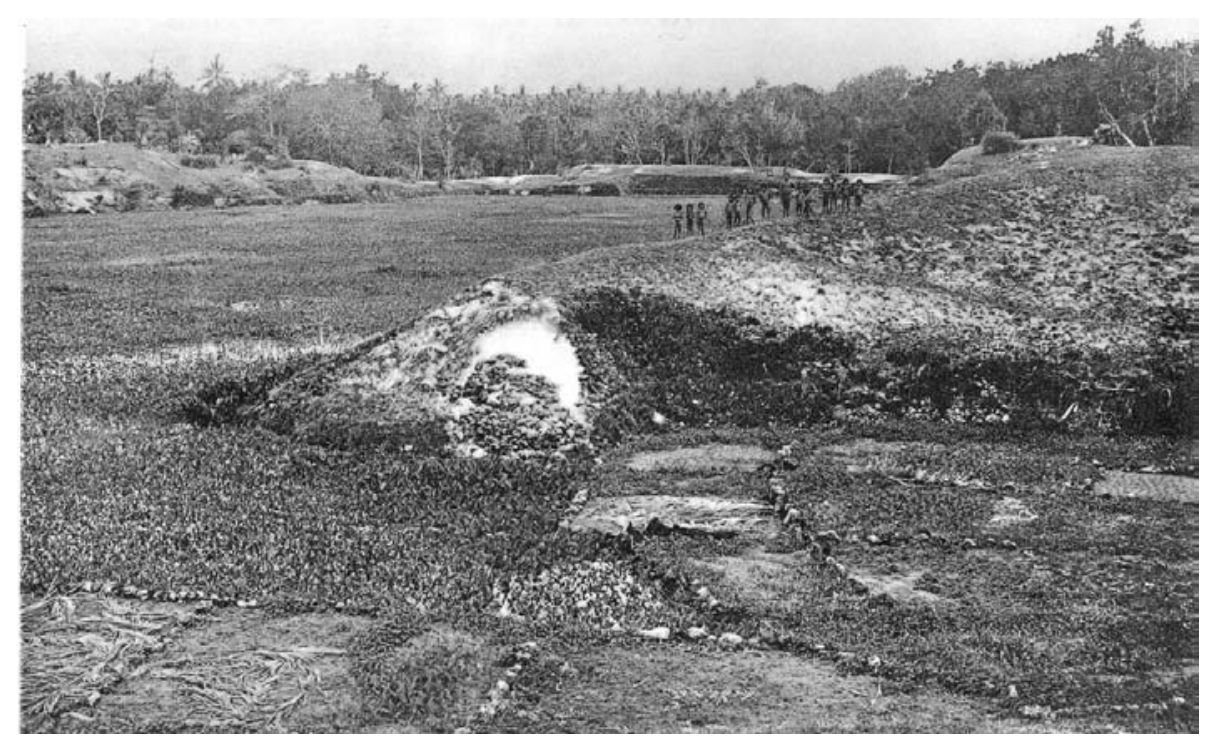

Figure 3. A large taro cultivation pit on Tobi Island in 1909 (after Eilers 1936).

ethnographic data (Eilers 1936; Johannes 1981) and many pelagic fish remains were excavated on Tobi by Intoh and Ono (2007). It is possible, therefore, that there was a specific situation that brought about the poor resource conditions that Holden and others experienced.

It must be noted that the Palauan chiefs who came with Holden did not know about Tobi Island and did not understand the language. Cultural contacts between the Southwest Islands and the main islands of Palau must have been very limited. This situation was quite different from that which existed between Yap and the Central Caroline Islands, where close cultural contacts have been maintained, despite their language differences.

\section{Language and ethnography: Palauan but not Palauan}

The language of the Southwest Islands belongs to the Nuclear Micronesian subgroup of the Micronesian family of Oceanic languages. The language is distinct from that spoken in the main archipelago of Palau, which is classified as a Western Malayo-Polynesian language (Bender 1971; Kikusawa 2005). Although both languages belong to subgroups within the Austronesian family, they are mutually incomprehensible.

Micronesian languages are also found in the Central and Eastern Caroline Islands, including the outer islands of Yap, Chuuk, Pohnpei and Kosrae. The Southwest Islanders easily communicate with these Caroline Islanders. The reason behind this is linked to the colonisation history of the Southwest Islands (Ross 1989; Rehg 1995; Intoh 1997). According to oral tradition, the Southwest Islands were settled by groups of people from the Central Caroline Islands, especially from Fais and Ulithi.

The dispersal history of the Micronesian languages is complex. The Micronesian languages belong to the Oceanic subgroup, and were probably originally derived from languages associated with the Lapita expansion (Green 1997; Kirch 2000:98). These languages are believed to have split off from the southeastern Solomons or central and northern Vanuatu around 2000 years ago or earlier (Blust 1984; Pawley and Ross 1993). The western movement within Micronesia was made through the Central Caroline Islands and spread to the Southwest Islands of Palau. The date for this movement was between 1800 BP and 1000 BP (Intoh 1997).

The languages of the Southwest Islands and the Central Caroline Islands are similar, but the number of shared words is relatively low. Also, a dialectal discontinuity exists between them 

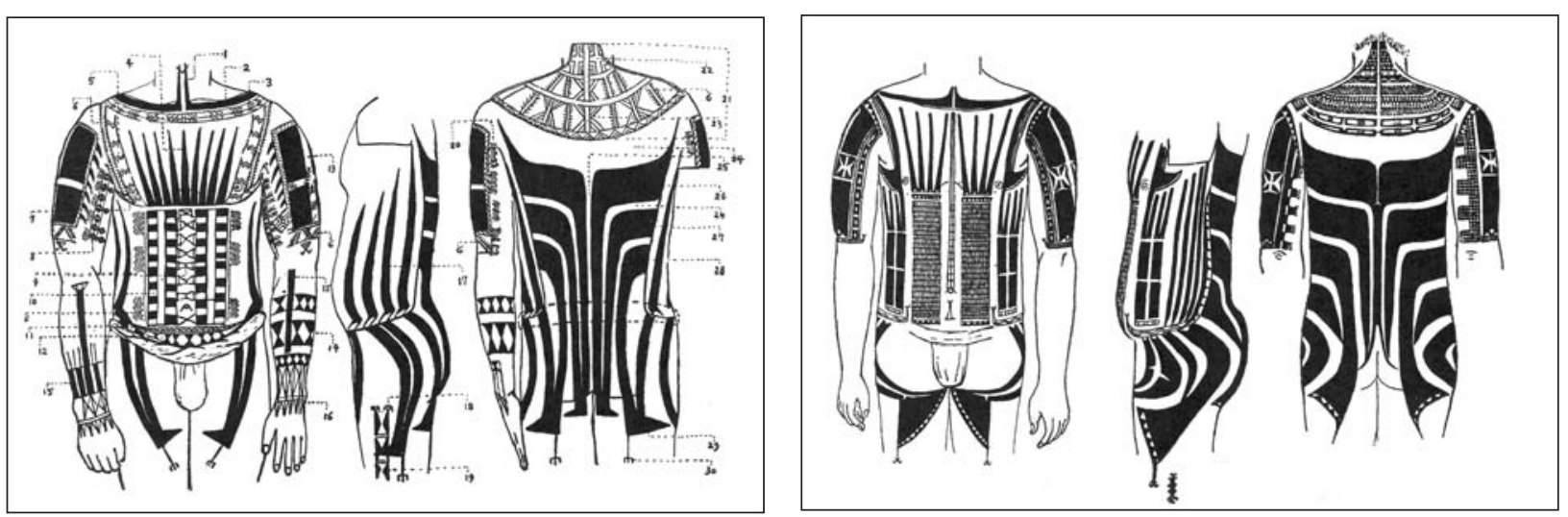

Figure 4. Tattoo designs in the Southwestern Islands of Palau and the Central Caroline Islands (after Hasebe 1928). Left to right: 4a, Sonsorol; $4 b$, Fais.

(Quackenbush 1968:108). This may indicate that these island groups did not have regular cultural contact after colonisation, which would be understandable, given the $600 \mathrm{~km}$ gap between Sonsorol and even the nearest Ngulu Atoll. On the other hand, there was a special relationship between the Southwest Islands and Ulithi. People from Ulithi once drifted to the Southwest Islands and as a result, they became relatives. Since then, whenever people from Ulithi have visited the Southwest Islands, they have been welcomed. However, the distance was too far to maintain regular contact (Lessa 1950). A similar relationship has been described between Fais and Tobi. These contacts were not more than accidental.

One of the cultural attributes shared between the Southwest Islanders and the Central Caroline Islanders was tattoo. The intricate design patterns covering almost the entire body recorded from both areas look very similar and indicate a shared tradition (Figure 4).

It is intriguing how people were able to continue to live on the Southwest Islands despite their resource-limited environment. There are no ethnographic records referring to a regular trade network like sawei between the main islands of Palau. This is verified by the scant pot sherds found from the Southwest Islands (Intoh and Ono 2007).

Loom weaving involves a set of sophisticated techniques that has a limited distribution in Oceania (Reisenberg and Gayton 1952). In the Central Caroline Islands, women wove their

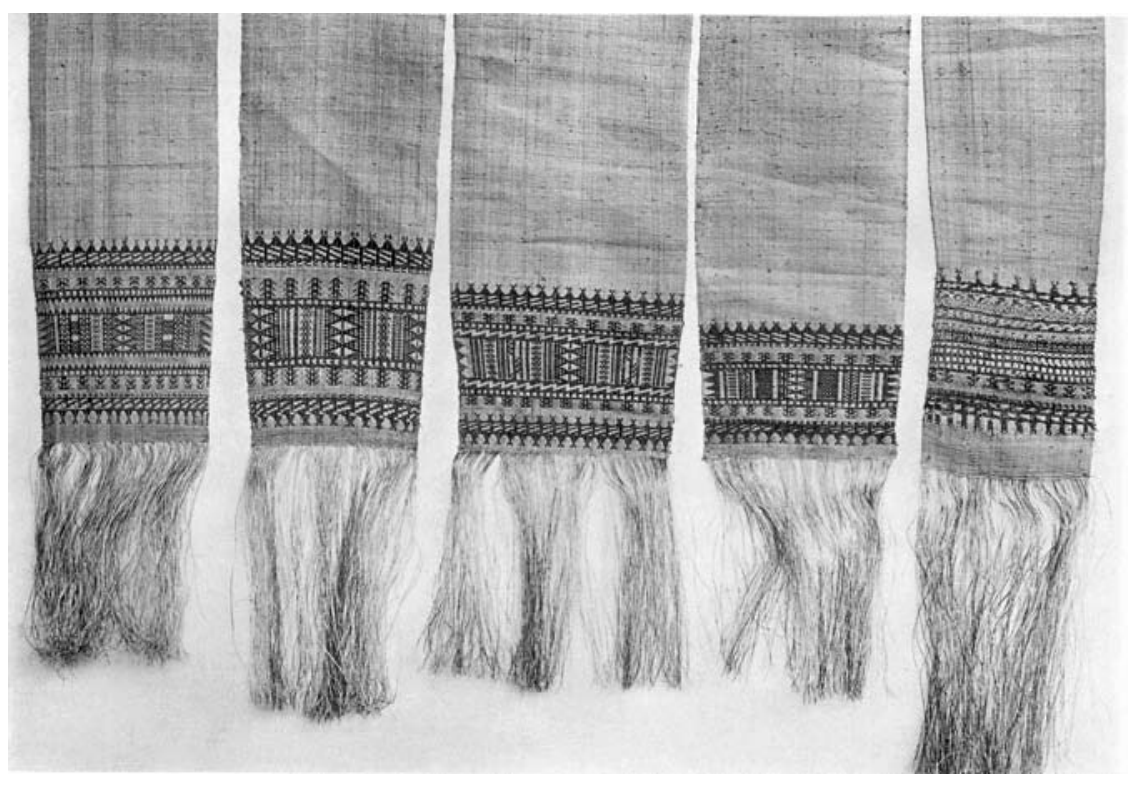

Figure 5. Woven cloth of Sonsorol (after Eilers 1935). 
own cloth and made special clothes with very intricate designs. The material used for weaving was banana, a plant that also grows on coral islands. Importantly, woven cloth was one of the significant trading goods offered from coral islanders to the Yapese and was worn by Yapese men with high social status. However, the islands of western Micronesia (Yap and Palau) did not possess any weaving technology, and the people wore grass skirts. ${ }^{4}$

The textile designs made on Sonsorol and Tobi in the early 20th century are very similar to those made in the Central Caroline Islands (Figure 5), and it is very likely the weaving technology of both areas shares a common origin, as does their language.

In historic times, some Palauan influence can be observed from photographs taken in 1903 by the German South Seas Expedition (Eilers 1936). For example, grass skirts were worn on Pulo Anna and Merir, while woven cloth was worn on Sonsorol and Tobi.

How can we account for the grass skirts observed on Pulo Anna and Merir? The style of the grass skirts (long with a tied top) shown in the photograph is very stylised and is identical to that used in Palau. Moreover, the way grass skirts were put on, well below the belly with a shell or turtle-shell belt above the waist, is exactly the same style as used in Palau (Figure 6a) and is different from the way Yapese grass skirts were worn (Figure 6b). This similarity shows a definite influence from Palau, possibly in historic times, since the weaving technology on Pulo Anna is known from historic records (Riesenberg and Gayton 1952). Also, when Akira Someki visited the Southwest Islands in 1934, he observed two wooden beaters for weaving on Pulo Anna and noted that weaving was still periodically done on Merir (Someki 1945:273-296). Moreover, he did not observe any female wearing woven cloth on Sonsorol. The custom had changed over about 30 years. This demonstrates cultural influence from mainland Palau in historic times. The situation is quite different in the Central Caroline Islands, where the weaving tradition has been maintained to the present.

Figure 6. A woman wearing a grass skirt. Left to right: $6 a$, Pulo Anna (after Eilers 1935); 6b, Yap (photo by Intoh, 1983).
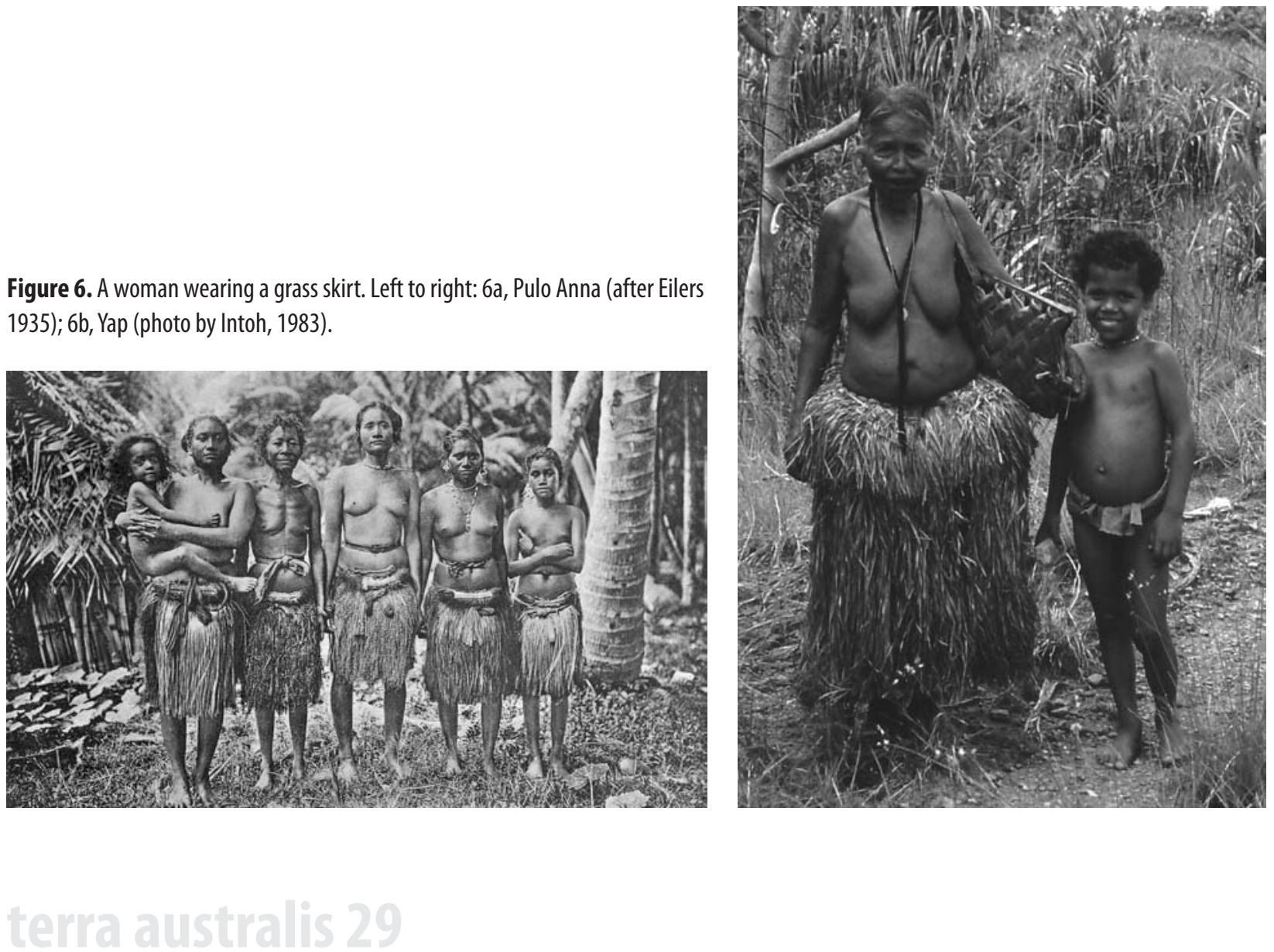


\section{Prehistory: External relationships}

The colonisation history of the main island group of Palau goes back more than 3000 years. Several archaeological sites have been excavated from raised coral islands surrounding Babeldaob. Dates associated with the sites are around 3000 BP (Fitzpatrick 2002; Clark 2005; Clark and Wright 2005; Liston 2005). The earliest people to settle the Palauan archipelago are believed to have come from somewhere in Island Southeast Asia or from New Guinea. Genetic studies suggest people in the main islands of Palau share several genetic traits with New Guinea populations (Lum and Cann 2000). The dispersal route is not clear, but dispersal is unlikely to have been through the Southwest Islands.

Three archaeological expeditions have been conducted in the Southwest Islands of Palau thus far.

The first expedition was conducted by Osborn in 1953 (Osborne 1966). This was limited to the observation of surface features and the collecting of some surface finds. A number of large and small mounds, possibly for dwellings, were recorded. A large dug-out taro cultivation pit and a large artificially built stone wall were documented on Tobi Island.

The second expedition was carried out by Rosalind Hunter-Anderson from Guam in 1992. Her research aimed to relocate the archaeological features recorded by Osborne and to make some test excavations (Hunter-Anderson 2000). She opened some test pits on Sonsorol, Pulo Anna, and Tobi. Most of the radiocarbon dates were less than 300 years before the present, except for one older date (about 1000 BP) obtained from Merir. This led Hunter-Anderson to conclude that the Southwest Islands were inhabited only in the very recent past.

The third expedition was carried out by Intoh and Ono in 2002. All the Southwest Islands except for Helen Reef were visited, and Tobi was chosen for a reconnaissance survey (Intoh and Ono 2006). A small number of Palauan pot sherds were observed on the ground surface and in private collections on Sonsorol and Pulo Anna. No pot sherds were found on Tobi from this research. However, as Hunter-Anderson obtained a few Palauan pot sherds from the surface, a few pots could have been imported from Palau.

The excavation was conducted in two places. One was at the infant burial ground associated with a women's house mound, and the other at a coastal deposit near the habitation area. Radiocarbon dates obtained from charcoal samples were 439 43 BP (AD 1400-1530) and 345 \pm 40 BP (AD 1450-1650) respectively (Intoh and Ono 2006:66-68). These dates are about 150 years older than those obtained by Hunter-Anderson. When other evidence, such as linguistic and ethnographic data, is considered, the Southwest Islands might have been colonised as early as $\mathrm{AD} 1400$.

These dates correspond to the linguistic studies that indicate a relatively late colonisation. It is plausible that the movement from east to west of people speaking Micronesian languages had paused in the Central Caroline Islands before they dispersed to the Southwest Islands. Accidental contacts could have been one of the possible motivations for colonisation. The Southwest Islands are the last area in Micronesia where speakers of a Micronesian language settled.

A variety of artefacts were obtained from excavation and from the ground surface. These include

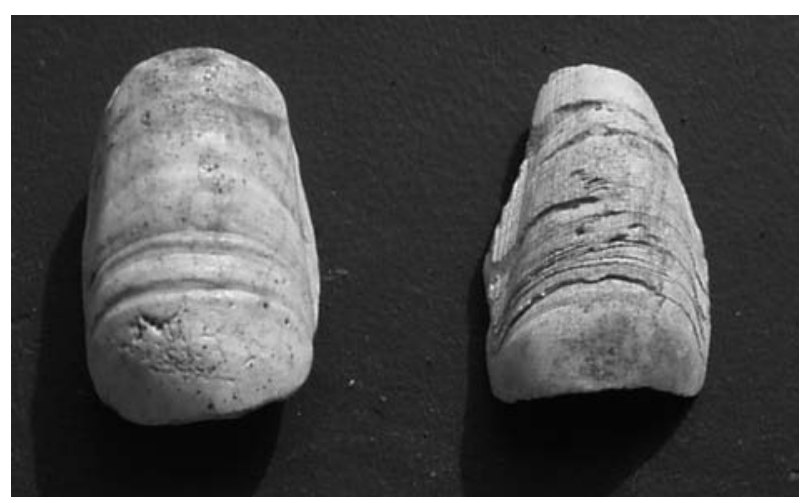

Figure 7. A Tridacna gigas shell adze/gouge (private collection on Tobi Island). 
Tridacna sp. shell adzes, shell ornaments (bracelets and beads), fishing lures for trolling, and single fishhooks made of turtle carapace. The most distinctive artefact is a heavy shell adze made of Tridacna gigas (Figure 7). This has a curved blade and was likely used as a gouge in heavy woodworking. Tridacna gigas used to be found around the island, but is now extinct, due to over fishing. Islanders are known to have obtained sea turtles and Tridacna gigas from Helen Reef in historic times (Johansen 1981). Importing of resources from nearby islands was apparently practised.

Considering the reasonable number of Tridacna gigas shell adzes observed in private collections on the island, it would appear that they may have been manufactured on the island. This may be related to the fact that a large number of canoes were used on Tobi. A total of 78 canoe houses were recorded in 1903 by the German South Sea Expedition (Eilers 1936). When the ship carrying Holden was wrecked off Tobi, about 18 canoes came out from the shore. It was also recorded that whenever someone died on the island, the corpse was put in a canoe to be thrown into the ocean (Holden 1836). A photograph of a reasonably large canoe under construction was taken on Pulo Anna in 1903 (Figure 8).

A number of trolling lures made of mother-of-pearl were observed in private collections in the Southwest Islands (Figure 9). The range of head shape is within the variation found in the Central Caroline Islands. Due to the narrow lagoon and the deep sea surrounding the reef, fishing with lures was the major fishing method on the island (Johansen 1981).

Most of the artefacts described above are found generally in Oceania and no influence from Indonesia or New Guinea was detected except for weaving. Occasional accidental contacts were obvious. For example, drift bamboo was used for house building and making a huge basket for trap fishing (Eilers 1936) (Figure 10). The possibility cannot be ruled out that a drift raft, or a canoe with people aboard could have run aground on the island.

\section{Discussion and conclusion}

The Southwest Islands of Palau consist of four raised coral islands and a small atoll. These islands were settled by speakers of a Micronesian language who emigrated from the Central Caroline Islands about 450-600 years ago. Between the Southwest Islands and the main islands of Palau, there is a considerable cultural and linguistic gap. The main islands were colonised by an earlier

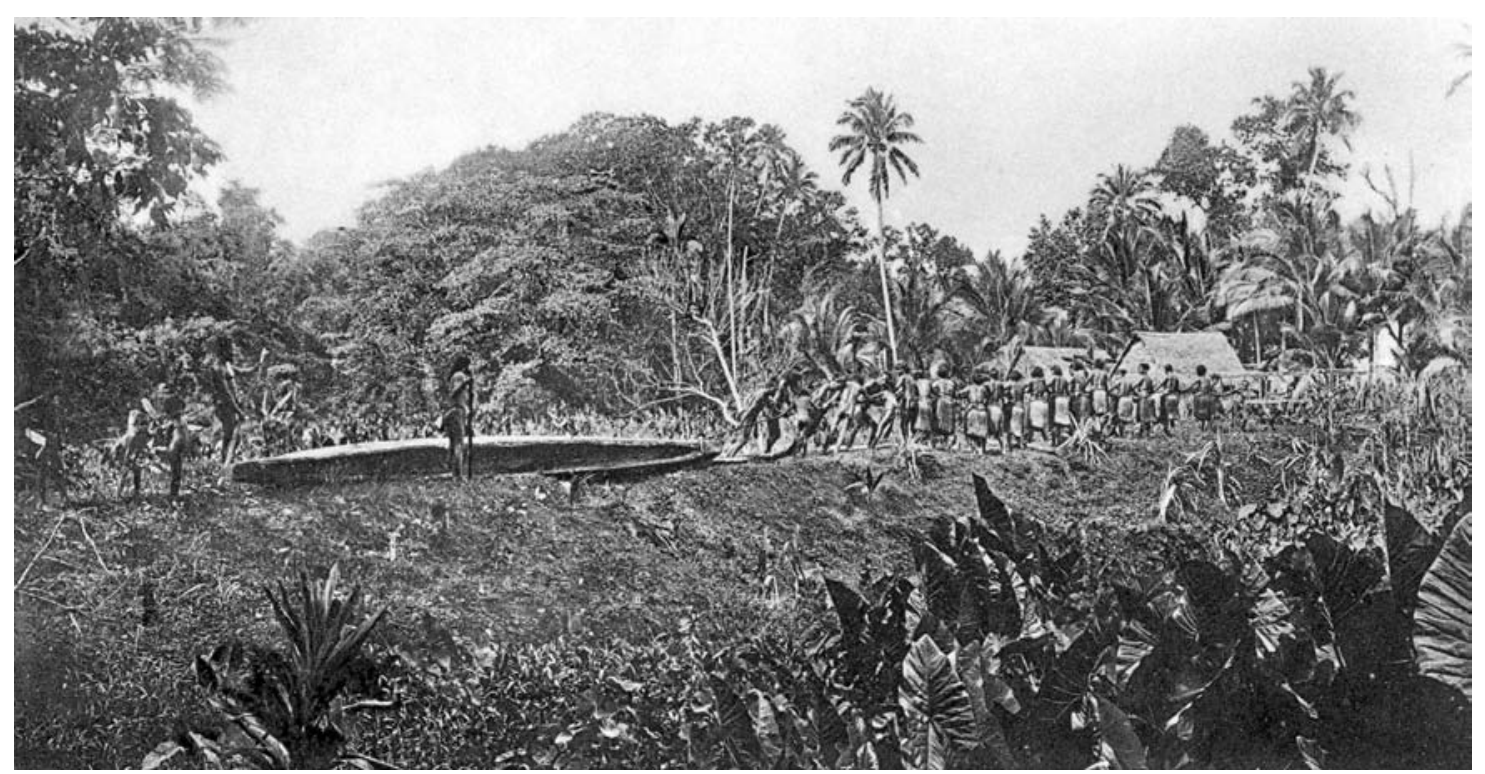

Figure 8. A large canoe under construction on Pulo Anna (after Eilers 1935). 
human population from Island Southeast Asia or New Guinea more than 3000 years ago, but there is neither linguistic nor archaeological evidence that indicates any sign of prehistoric cultural contact between western Micronesia and Island Asia and New Guinea.

The Southwest Islands are in the vicinity of Micronesia, Melanesia and Island Southeast Asia and evidence of cultural interaction among these areas was expected. One of the cultural traits is weaving technology. The distribution of loom weaving was confined to the Southwest Islands of Palau, Central and Eastern Caroline Islands and the small islands of northern Melanesia (Lessa

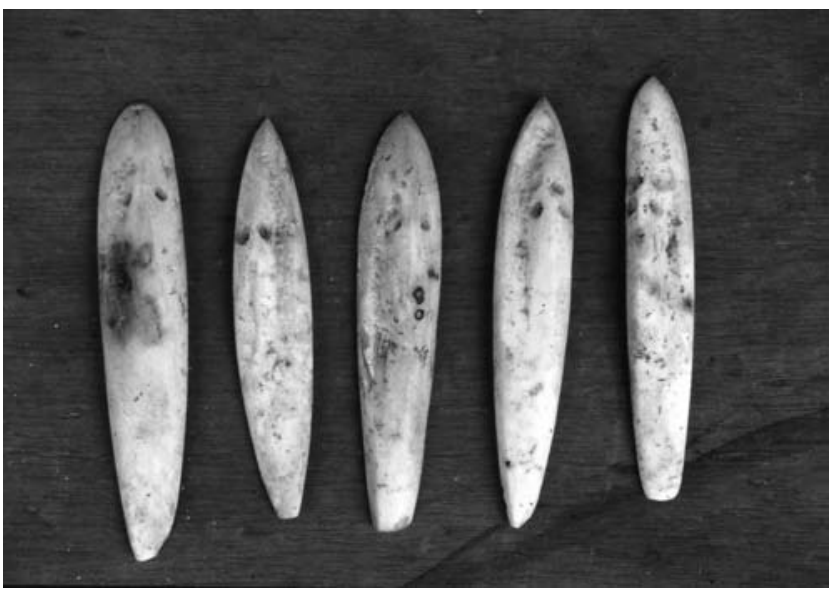

Figure 9. Trolling lures made of mother-of-pearl shell (private collection on Tobi). 1978).

Technological analysis suggests weaving was dispersed from Indonesia to the Caroline Islands and subsequently to Melanesia (Riesenberg and Gayton 1952). The direction is the opposite of that proposed by the linguistic model of human movement. It is possible that the central Caroline Islanders made accidental contacts with Indonesian islands and brought back weaving technology. However, it seems there was not a single one-way dispersal, but several, judging from the distribution of weaving in Melanesia. In any case, it is unclear whether introduction of weaving from Indonesia to Melanesia was direct, or whether the Southwestern Islands were the dispersal route.

However, it is difficult to understand how weaving technology could have spread all the way to Kosrae in the East Caroline Islands, since there was very little active interaction beyond Chuuk once permanent settlement was made. Perhaps Polynesian Outliers could have played a significant role in this cultural diffusion, since most of the Polynesian outliers had similar looms and weaving technology.

There is very limited evidence of contact between the Southwest Islands and the main island group of Palau, which contrasts with the close relationship between the Yapese and Central Caroline Islanders. A number of cultural attributes of the Southwest Islands, such as canoe types, tattoo designs, weaving techniques and design elements, show considerable similarities with the Central Caroline Islands from where colonisation probably began. There is little evidence showing cultural contact with the main islands of Palau. However. Palauan female fashions were introduced to some of the Southwest Islands by the end of 19th century.

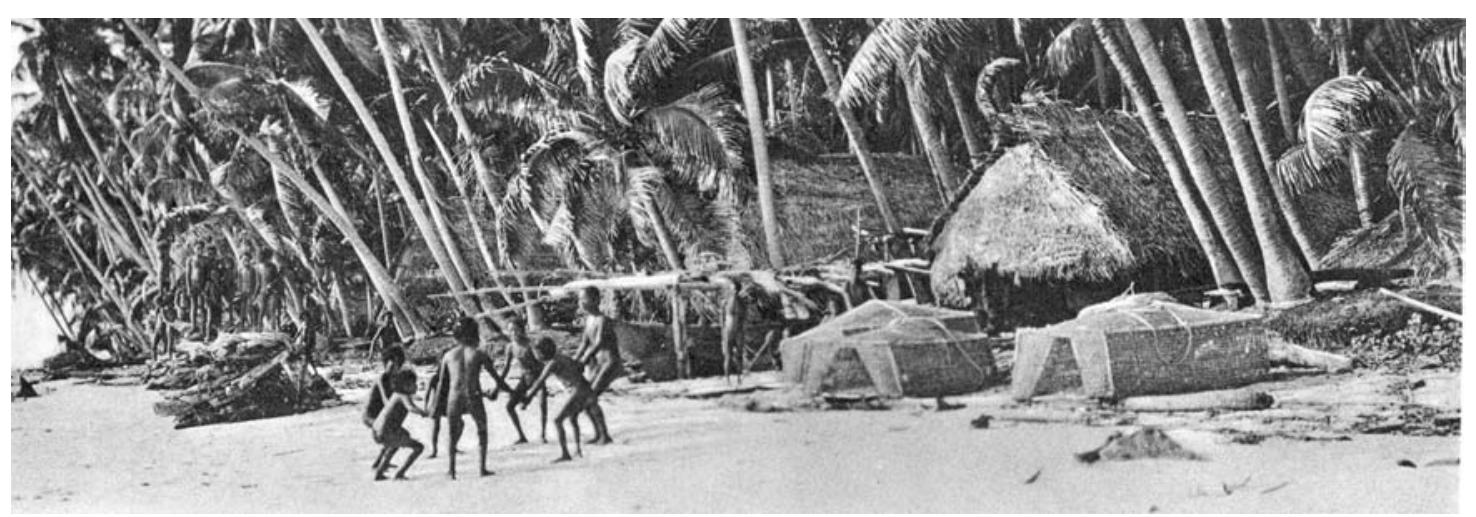

Figure 10. Large basket bamboo fish traps on Tobi (after Eilers 1936). 
In sum, the history of human habitation in the Southwest Islands of Palau is not extensive. The islands did not serve as stepping stones to colonise the main islands of Palau. The strong founding influence from the Central Caroline Islands (language and cultural traits) has been retained. External contacts for resource management seem not to have been active between the islands. Laborious land modifications were made for resource intensification, the techniques similar to those used in the Central Caroline Islands. The high frequency of shared words among the Southwest Islands could also indicate that cultural contact was maintained between the islands and that colonisation was probably relatively recent. Further work is needed to examine the role of the Southwest Islands in the introduction of loom-weaving to Micronesia.

\section{Endnotes}

1. It was recorded that about 30 drifted canoes were found on Samar in the Philippines in 1664 (Hezel 1983:40).

2. The distribution of the Austronesian domesticated animals, pig, dog and chicken, was irregular in Micronesia. Only Fais Island is known to have archaeological evidence of all (Intoh1986; Intoh and Shigehara 2004).

3. The recent population is much smaller, however. Only about 20 lived there in 2002, compared with 968 in 1909 (Black 1977). Overpopulation is also likely to explain such poor food conditions.

4. Weaving was practised in Yap by the outer islanders living in Yap. Yapese women did not themselves wear woven cloth.

\section{Acknowledgements}

Atholl Anderson made a strong impression on me when I was a student at Otago University. His active fieldwork and extensive writings were a great incentive to me and were valuable for my later academic career in Japan. My sincere thanks go to the people on Tobi, Palau, the Historic Preservation Office, and to Rintaro Ono for their help and enthusiasm during the archaeological research carried out on Tobi in 2003.

\section{References}

Alkire, W.H. 1978. Coral Islanders. Illinois: AHM Publishing.

Bender, B. 1971. Micronesian languages. In T.A Sebeok (ed), Linguistics in Oceania. Current Trends in Linguistics 8, pp. 426-465. The Hague: Mouton.

Black, P.W. 1977. Neo-Tobian culture. Unpublished PhD thesis, University of California.

Blust, R. 1984. Malaita-Micronesian: an Eastern Oceanic subgroup? Journal of the Polynesian Society 93(2):99-140.

Clark, G.R. 2005. A 3000-year culture sequence from Palau, Western Micronesia. Asian Perspectives 44(2):349-380.

Clark, G.R. and D. Wright 2005. On the periphery? Archaeological investigations at Ngelong, Angaur island, Palau. Micronesica 38(1):67-91.

Eilers, A. 1935. Westkarolinen. Ergebnisse der Südsee-Expedition 1908-1910, II.9i, Hamburg:

Friederichsen de Gruyter. 
Eilers, A. 1936. Westkarolinen: Tobi und Ngulu. Ergebnisse der Südsee-Expedition 1908-1910, II, B.9, ii. Hamburg: Friederichsen de Gruyter.

Fitzpatrick, S.M. 2002. A radiocarbon chronology of Yapese stone money quarries in Palau. Micronesica 34(2):227-242.

Green, R. 1997. Linguistic, biological, and cultural origins of the initial inhabitants of Remote Oceania. New Zealand Journal of Archaeology 17:5-27.

Hasebe, K. 1928. Togobei toumin ni tuite [On the islanders of Tobi]. Jinruigaku Zasshi (Journal of the Anthropological Society of Nippon) 43(2):63-70.

Hezel, F.X. 1983. The First Taint of Civilization: A History of the Caroline and Marshall Islands in PreColonial Days, 1521-1885. Pacific Islands Monograph Series 1. Honolulu: University of Hawaii Press.

Hezel, F.X. and M.T.D. Valle 1972. Early European contact with the Western Carolines: 1525-1750. Journal of Pacific History 7:26-44.

Holden, H. 1836. A Narrative of the Shipwreck, Captivity and Sufferings of Horace Holden and Benjamin H. Nute: who were cast away in the American ship Mentor, on the Pelew Islands, in the year 1832. Boston: Russell Shattuck.

Hunter-Anderson, R.L. 2000. Ethnographic and archaeological investigations in the southwest islands of Palau. Micronesia 33(1/2):11-44.

Intoh, M. 1986. Pigs in Micronesia: introduction or re-introduction by the Europeans. Man and Culture in Oceania 2:1-26.

Intoh, M. 1997. Human dispersals into Micronesia. Anthropological Science 105(1):15-28.

Intoh, M. 2008. Introduction. In M. Intoh (ed), Seitaishigen to Shouchouka [Natural Resources and Symbolization]. Shigenjinruigaku [Anthropology of Resource Management] 7, pp.13-23. Kobundo, Tokyo.

Intoh, M. and R. Ono 2006. Reconnaissance Archaeological Research on Tobi Island, Palau. People and Culture in Oceania 22:53-83.

Intoh, M. and N. Shigehara 2004. Prehistoric pig and dog remains from Fais island, Micronesia. Anthropological Science 112:257-267.

Johannes, R.E. 1981. Words of the Lagoon. Berkeley: University of California Press.

Kikusawa, R. 2005. Mikuronesia no gengo [Languages of Micronesia]. In M. Intoh (ed), Mikuronesiawo Sirutameno 58 Shou [58 Chapters to learn about Micronesia], pp. 48-52. Tokyo: Akashi Shoten Co.

Kirch, P.V. 2000. On the Road of the Winds: An Archaeological History of the Pacific Islands before European Contact. Berkeley: University of California Press.

Lessa, W.A. 1950. Ulithi and the outer native world. American Anthropologist 52:27-52.

Lessa, W.A. 1978. The Mapia islands and their affinities. In N.Gunson (ed), The Changing Pacific: Essays in Honour of H.E. Maude, pp. 228-245. Melbourne: Oxford University Press.

Liston, J. 2005. An assessment of radiocarbon dates from Palau, western Micronesia. Radiocarbon 47(2):295-354.

Lum, J.K. and R.L. Cann 2000. MtDNA lineage analyses: Origins and migrations of Micronesians and Polynesians. American Journal of Physical Anthropology 113:151-168.

Osborne, D. 1966. The Archaeology of the Palau Islands: An Intensive Survey. B.P. Bishop Museum Bulletin 230. Honolulu, Bishop Museum Press.

Pawley, A. and M. Ross 1993. Austronesian historical linguistics and culture history. Annual Review of Anthropology 22:425-459.

Petersen, G. 1999. Sociopolitical rank and conical clanship in the Caroline islands. The Journal of the Polynesian Society 108(4):367-410.

Riesenberg, S.H. and A.H. Gayton 1952. Caroline Island belt weaving. Southwestern Journal of Anthropology 8:342-375. 
Rehg, K.L. 1995. The significance of linguistic interaction spheres in reconstructing Micronesian prehistory. Oceanic Linguistics 34:305-326.

Quackenbush, E.M. 1968. From Sonsorol to Truk: A dialect chain. Unpublished PhD thesis, Department of Anthropology, University of Michigan.

Ross, M.D. 1989. Early Oceanic linguistic prehistory. Journal of Pacific History 24(2):135-149.

Someki, A. 1945. Nanyou no Fudo to Mingu [Environment and Material Culture of the South Seas]. Tokyo,Shoko Shoin, Co.Ltd. 